\title{
AN EMPIRICAL ANALYSIS OF STOCK PRICE BEHAVIOUR AROUND BONUS ISSUE ANNOUNCEMENT IN INDIA
}

\author{
Poonam Kumari \\ Research Scholar, Department of Commerce, \\ Central University of Rajasthan, Ajmer, India \\ Pushpender \\ Research Scholar, Department of Commerce \\ Central University of Rajasthan, Ajmer, India
}

\begin{abstract}
Corporate actions announcement is usually assumed to offer good news to participants in market. In case of fictitious corporate action such as Bonus share issue, tend to react on market price positively or negatively. In light of this, present study aims to investigate the impact of Bonus Issue announcement on Indian stock market for the period of five years from 2014 to 2018. We applied event study methodology using a sample size of nine companies from BSE. Percentage Analysis, CAGR (Compounded Annual Growth Rate), Mean, Standard Deviation, Regression Analysis and t-test as statistical tools have been used to analyse and interpret the data. Investigation window ( $t_{-10}$ to $\left.t_{+10}\right)$ taken for all bonus issue announcement event to test the abnormal return considering nine companies. The result reveals that Indian Stock market does not react to bonus share issue announcement. Thus, this paper contributes to the fact that there is no significant effect on stock price when a company announces the issue of bonus shares.
\end{abstract}

Keyword: Stock Price, Stock India, Stock Market, CAGR

Cite this Article: Poonam Kumari and Pushpender, An Empirical Analysis of Stock Price Behaviour around Bonus Issue Announcement in India. Journal of Management, 6(1), 2019, pp. 186-196.

http://www.iaeme.com/jom/issues.asp?JType=JOM\&VType=6\&IType=1

\section{INTRODUCTION}

The term 'bonus issue' refers to the distribution of new shares to the existing shareholders. In this, no subscription price has been charged from the existing shareholders and new shares have been issued in proportion of existing shares holdings. Company's bonus issue increase the share capital but there is no involvement of cash flows. Announcement of issue of bonus shares has the significant effect on the market price of shares. A company can issue bonus shares by using 
its retained earnings and capital reserves. Issue of bonus shares do not enhance the earning power and also not reduces the expenses, when working on the assumption that there is no information asymmetry. The event bonus issue has a significant market price reaction. The aim of this paper is to examine the effect of announcement of issue of bonus shares on the stock prices of National Stock Exchange.

Sometimes stock split and bonus issue terms are used interchangeably, although these terms have different meanings. A stock split is a "method to increase the number of outstanding shares through a proportional reduction in the par value of the share." If the shares are not split periodically, then small investors would shy away from stock whose market price are high. While bonus shares are simply issuing of additional shares to the existing shareholders. The difference between the two are that stock split divides the price of all old shares into smaller par value without effecting the total capital, and bonus issue is the distribution of new shares into existing shareholders, that leads to increase in total capital of the company.

Eugene Fama (1991) introduced the concept of Efficient Market, it is the market which adjusts itself rapidly according to new information and reflects all information in its prices. There are three forms of market efficiency as follows:

- Weak- form efficiency

- Semi-strong efficiency

- $\quad$ Strong- form efficiency

Weak form of efficient market assumes that stock prices reflect all information that can be obtained by examining the past prices. Serial correlation tests, Run tests, Filters rules tests are available for testing of weak form of efficiency. It can be said that in an efficient market no investor, traders or any participants can earn superior returns or abnormal returns by trading policies. Semi-strong form of efficient market reflects all public information as well as historical data. There are three methods for semi-strong form efficiency as follows:

- Event study

- Portfolio study

- Times series analysis.

Thereafter, strong form of efficient market indicates that stock prices adjust according to all public, private information and historical data. The classification of the tests into weak, semistrong and strong form serves the purpose of identifying the level of information at which the hypothesis breaks down.

The efficient market hypothesis is based on Random Walk Theory. Random Walk Theory says that the future stock prices are identically distributed and are independent of past prices that mean successive stock prices do not follow any past patterns because this information is freely available to all the participants free of cost. According to Fama (1991), "the theory of the EMH of financial markets holds that the security prices tend to fluctuate randomly around their intrinsic values, return quickly move towards equilibrium, and fully reflect the latest information available." Like Bonus issue, the stock split has an informational value that the company is expected to perform profitably and proficiently in future and shares are split in order to avoid high price per share in future.

\subsection{SEBI guidelines on bonus issue are given below:}

- Only free reserves can be used for issue of bonus shares.

- Bonus issue cannot be partly paid up (there should be issue of fully paid up shares only. 
- If a company defaulted in payment of interest, then it cannot issue bonus shares.

- There should be provision of bonus issue in memorandum and articles of association.

- Issue has been made within 6 months from the date of meeting of Board of Directors.

In finance, the topic of empirical discussion is the relationship between bonus issue and share price. Some of the empirical researches have shown that market generally react positively with the announcement of bonus issue, on the other hand some studies talked about the reasons of reaction of market prices. Moreover, some talked about the change in liquidity position due to bonus issue announcements. The focus of this paper is to analyse the impact of announcement of bonus issue on National Stock Exchange from period 2014-2018.

Further, this paper is organised in five sections viz. literature review, research methodology, results and analysis, followed by conclusion of the study.

\section{REVIEW OF LITERATURE}

A wide number of studies have been conducted across the world to examine the applicability of semi strong form of efficient market hypothesis to the stock markets of many developed as well as emerging economies in the context of different corporate events like announcement of stock split, stock dividend, right issue, bonus issue, financial results etc.

Table 1 Methodology

\begin{tabular}{|c|c|c|}
\hline Author's Name & Title of the Paper & Methodology and Findings \\
\hline $\begin{array}{c}\text { Below and Johnson } \\
(1996)\end{array}$ & $\begin{array}{l}\text { "An Analysis of } \\
\text { Shareholder Reaction to } \\
\text { Dividend } \\
\text { Announcements in Bull } \\
\text { and Bear Markets" }\end{array}$ & $\begin{array}{c}\text { The study examined the differential share price reaction to } \\
\text { change in dividend announcements with respect to market } \\
\text { phase. The study found that market phase has a significant } \\
\text { impact on abnormal returns around the announcement and it } \\
\text { appeared that more information is conveyed by dividend change } \\
\text { announcements which runs counter to market phase and these } \\
\text { results were consistent with the information content of } \\
\text { dividends hypothesis. }\end{array}$ \\
\hline Gupta (2003) & $\begin{array}{l}\text { "Announcement Effects } \\
\text { of bonus Issues on Equity } \\
\text { Pri ces: The Indian } \\
\text { experience" }\end{array}$ & $\begin{array}{c}\text { The study examined the semi-strong form of efficiency of } \\
\text { Indian stock market in the event of the announcement of bonus } \\
\text { issues of } 145 \text { stocks during the period from 1995-2000 and } \\
\text { found evidence in favor of semi strong form of pricing } \\
\text { efficiency. }\end{array}$ \\
\hline Mishra (2005) & $\begin{array}{l}\text { "An Empirical Analysis } \\
\text { of Market Reaction } \\
\text { Around Bonus Issues in } \\
\text { India" }\end{array}$ & $\begin{array}{l}\text { The study tested whether Indian stock market is semi strong } \\
\text { form efficient or not by examining the stock price reaction to } \\
\text { the informational content of bonus issue. . The study found on } \\
\text { an average, a positive abnormal returns on nine to eight days } \\
\text { before the announcement date and on three days }(-9,-8 \text {, and }-6) \\
\text { it was found statistically significant; this may be due to leakage } \\
\text { of information. and the significant CAAR were found on these } \\
\text { days. On the announcement day a negative in-significant AAR } \\
(-0.19 \%) \text { was found }\end{array}$ \\
\hline $\begin{array}{c}\text { Dhar and } \\
\text { Chhaochharia (2008) }\end{array}$ & $\begin{array}{l}\text { "Market Reaction Around } \\
\text { the Stock Splits and } \\
\text { Bonus issues: Some } \\
\text { Indian Evidence" }\end{array}$ & $\begin{array}{l}\text { The study analyzed the impact of the information relating to the } \\
\text { announcements of stock splits and bonus issues on stocks listed } \\
\text { on NSE by employing event study. Both the events, which are } \\
\text { stock splits and bonus issues, reflected significantly positive } \\
\text { announcement effect. For bonus issues, the abnormal return was } \\
\text { about } 1.8 \% \text { and for stock splits it was about } 0.8 \% \text {. Thereby the } \\
\text { study supported the view that Indian stock market is semi strong } \\
\text { form efficient. }\end{array}$ \\
\hline $\begin{array}{l}\text { Raja and Clement } \\
\text { Sudhahar (2010) }\end{array}$ & $\begin{array}{l}\text { "An empirical test of } \\
\text { Indian Stock Market } \\
\text { efficiency in respect of } \\
\text { Bonus Announcement" }\end{array}$ & $\begin{array}{l}\text { The study empirically examined the informational efficiency of } \\
\text { Indian capital market regarding bonus issue announcements by } \\
\text { IT companies in BSE. } 43 \text { companies comprised as samples over } \\
\text { the period of study (2000-2007). Standard event study }\end{array}$ \\
\hline
\end{tabular}




\begin{tabular}{|c|c|c|}
\hline & & $\begin{array}{l}\text { methodology was adopted to test the efficiency. It was found } \\
\text { that positive significant AAR was found before the } \\
\text { announcement day. On announcement day, day } 1 \text { and day } 4 \\
\text { positive significant abnormal returns were found, that showed } \\
\text { that the shareholders have earned abnormal returns. CAARs } \\
\text { before announcement period were ranged from }-2.11 \text { to } 12.4 \\
\text { and on announcement day it was found } 14.46 \text { which increased } \\
\text { to } 17.16 \text { on day } 2 \text {. This revealed that market immediately } \\
\text { reacted to the bonus announcement. Hence it can be said that in } \\
\text { general, Indian capital market was efficient but not perfectly. }\end{array}$ \\
\hline $\begin{array}{l}\text { Kumar and Halageri } \\
\qquad(2011)\end{array}$ & $\begin{array}{l}\text { "Testing of semi strong } \\
\text { form efficiency of Indian } \\
\text { stock Market with respect } \\
\text { to Information content of } \\
\text { Bonus Announcement" }\end{array}$ & $\begin{array}{l}\text { The study attempted to test market efficiency of the Indian } \\
\text { stock market using the event study methodology and focused on } \\
\text { tonus issuance event from April } 1996 \text { to March } 2001 \text {, the event } \\
\text { period consist of } 15 \text { days before and after the announcement } \\
\text { date and } 54 \text { bonus announcement from listed companies were } \\
\text { studied. The result indicated that the Indian stock markets did } \\
\text { not perfectly incorporate bonus announcement information } \\
\text { instantaneously in the stock price. This meant that it is possible } \\
\text { to make abnormal returns from bonus announcement by } \\
\text { applying the buy and hold investment strategy. }\end{array}$ \\
\hline Ray (2011) & $\begin{array}{l}\text { "Market Reaction to } \\
\text { Bonus Issues and Stock } \\
\text { Splits in India: An } \\
\text { Empirical Study" }\end{array}$ & $\begin{array}{l}\text { The study attempted to test the Indian equity market in its semi- } \\
\text { strong form of efficiency. An event study approach was } \\
\text { followed considering the bonus issue and stock split as an event } \\
\text { during the period } 1996 \text { to } 2008 \text {. - } 30 \text { to } 30 \text { days event window } \\
\text { had been taken for testing the abnormal return and changes in } \\
\text { liquidity. It was found that the Indian stock market react to } \\
\text { stock split announcements and not to bonus issue. The change } \\
\text { in liquidity was found significant for stock split at } 1 \% \text { level of } \\
\text { significance, whereas at 5\% significance level both the events } \\
\text { showed significant change in liquidity from pre to post event } \\
\text { period. }\end{array}$ \\
\hline $\begin{array}{l}\text { Satija, Purohit and } \\
\text { Chhatwal (2012) }\end{array}$ & $\begin{array}{l}\text { "Market Reaction Around } \\
\text { the Announcement of } \\
\text { Stock Split and Bonus } \\
\text { Issue in India: An } \\
\text { Empirical Analysis" }\end{array}$ & $\begin{array}{l}\text { The study attempted to examine the informational efficiency of } \\
\text { Indian stock market in its semi-strong form by considering two } \\
\text { corporate events bonus issue and stock split announcement. } 16 \\
\text { stock splits and } 23 \text { bonus issue announced by companies listed } \\
\text { in CNX } 100 \text { index were taken as samples during the study } \\
\text { period } 1 \text { January } 2006 \text { to } 1 \text { January } 2011 \text {. Event study } \\
\text { methodology was adopted with } 41 \text { days event window and t-test } \\
\text { was used to test the significance. The study found very } \\
\text { negligible reactions on or before the announcement date. In } \\
\text { overall, it was found that pattern of AARs and CAARs were in } \\
\text { accordance with expectations, and supported the hypothesis that } \\
\text { Indian stock market was semi-strong form efficient. }\end{array}$ \\
\hline $\begin{array}{c}\text { Liu Hua and } \\
\text { Skanthavrthar } \\
\text { Ramesh (2013) }\end{array}$ & $\begin{array}{l}\text { "A Study on Stock Split } \\
\text { Announcements and its } \\
\text { Impact on stock Prices in } \\
\text { Colombo Stock Exchange } \\
\text { (CSE) of Sri Lanka" }\end{array}$ & $\begin{array}{l}\text { The study scrutinized the stock prices response to stock split } \\
\text { announcement and tested market efficiency in CSE. Standard } \\
\text { event study methodology was employed using } 64 \text { sample events } \\
\text { during the period } 2009 \text { to } 2012 \text {. It was found that Average } \\
\text { abnormal return }(1.46 \%) \text { is statistically significant at } 5 \% \\
\text { significance level on the announcement date and large negative } \\
\text { cumulative average abnormal return (-6\%) is found during the } \\
\text { period (0-10) that means stock splits have a significant signal } \\
\text { and information content in CSE. This study supported the semi- } \\
\text { strong form of EMH. }\end{array}$ \\
\hline $\begin{array}{c}\text { Ramachandran } \\
\text { (2013) }\end{array}$ & $\begin{array}{l}\text { "A study on Semi-Strong } \\
\text { Efficiency of Indian } \\
\text { Stock Market" }\end{array}$ & $\begin{array}{l}\text { The study examined the efficiency of Indian stock market by } \\
\text { analyzing the corporate events i.e. dividend, stock split, merger } \\
\text { and bonus issue announcements. Five year period ( } 1^{\text {st }} \text { April } \\
2004 \text { to } 31^{\text {st }} \text { March } 2009 \text { ) was taken as time frame of the study } \\
\text { and an event study methodology was adopted to test the } \\
\text { efficiency by considering } 60 \text { days event window. Statistical } \\
\text { tools such as t-test, z-test and nonparametric u-test were used to }\end{array}$ \\
\hline
\end{tabular}




\begin{tabular}{|c|c|c|c|}
\hline & & $\begin{array}{c}\text { test the impacts of various events. It was found that the } \\
\text { information release of dividend, stock split, bonus issue and } \\
\text { merger announcements don't significantly influenced the } \\
\text { security returns. This revealed that investors were not able to } \\
\text { earn abnormal returns on the release of these four corporate } \\
\text { events. The results of study revealed that the semi-strong form } \\
\text { of Indian stock market was efficient. }\end{array}$ \\
$\begin{array}{c}\text { Ajayi John Ayodele, } \\
\text { Ogbulu Onyemachi } \\
\text { Maxwell (2016) }\end{array}$ & $\begin{array}{c}\text { Test of the Semi-Strong } \\
\text { Efficiency Theory in the } \\
\text { Nigerian Stock Market: } \\
\text { An Empirical Analysis }\end{array}$ & $\begin{array}{c}\text { This study used input-output index to study semi-strong } \\
\text { efficiency theory and took period from Jan. 2005 to Dec. 2013. } \\
\text { The results of the study showed that public information have the } \\
\text { significant impact on the stock market of Nigeria. }\end{array}$ \\
\hline $\begin{array}{c}\text { Effect of Bonus Issue on } \\
\text { stock price of companies } \\
\text { quoted at the Nairobi } \\
\text { securities exchange. }\end{array}$ & $\begin{array}{c}\text { This study adopted event study methodology to see the impact } \\
\text { of bonus issue on stock prices. It took sample size of 10 } \\
\text { companies from the population of 60 listed companies in NSE } \\
\text { and period from 2009-2012. This study concluded that bonus } \\
\text { issue results in abnormally higher returns and bonus issue } \\
\text { announcements result in higher market returns than normal } \\
\text { expected returns. }\end{array}$ \\
\hline
\end{tabular}

After reviewing the literature, it has been found that a wide number of studies have been conducted across the world to test market efficiency of the stock markets of many developed as well as emerging economies in the context of different corporate events like stock split, bonus issue, right shares etc., but few studies are found in the context of corporate announcement. The present study serves by taking bonus issue data during time period of five years from January 2014 to December 2018 in National Stock Market.

\section{STATEMENT OF THE PROBLEM}

With the growing aspirations of the domestic and foreign investors for participating in Indian stock market, increasing rate of information flow in the market and communication technology, immense opportunities for trading in a wide range of stocks, stock indices and corresponding derivatives, wide scope is there for Indian stock market to improve the level of its pricing efficiency and thereby stimulating the economic growth of the country. This provides opportunity to researchers to empirically examine the pricing efficiency of the Indian stock market. The present study focuses on whether the Indian Stock Market is efficient in the context of the impact of bonus issue announcements on the price behavior of NSE stocks.

\section{RESEARCH METHODOLOGY}

\subsection{Scope of the study}

The present study is conducted to test the market efficiency of Indian capital market in the context of impact of bonus issue announcements on the stocks of NSE. It covers nine companies listed in NSE over the time frame of five years. The outcome of the study may be useful to the individual and retail investors and portfolio managers in formulating suitable investment strategies and risk management strategies. Moreover, the study may provide pertinent information to the market regulators and policy makers in adopting appropriate measures and policies so that the market can properly perform its role in the matter of risk transference and price discovery.

\subsection{Research Design}

Empirical cum analytical research design is used in the study. The efficient market hypothesis is tested by analyzing the speed of adjustment of stock price to new information. The data set for analyzing the stock price movements around bonus issue announcements were formed by adopting the following criteria: 
- The availability of the date of bonus issue announcements of the companies belonging to National Stock Exchange.

- The availability of daily closing stock price data over a period of 120 days during the estimation window and 21 days during the event window.

\subsection{Objectives}

The present study objective is to check the market efficiency of National Stock Exchange (NSE) and examine whether the announcement of bonus issue by the NSE companies impact the market prices of share.

\subsection{Hypothesis}

The present study examines stock market returns to assess the impact of stock bonus issue announcement and the following hypotheses are set:

$\mathrm{H}_{0}$ : There is no significant impact of announcement of bonus issue on the stock market prices of NSE companies.

$\mathrm{H}_{1}$ : There is significant impact of announcement of bonus issue on the stock market prices of NSE companies.

The study comprises eight companies (whereas bonus issue event happened nine times) which had announced bonus issue during the study period 2014-2018, and have been listed in NSE.

Table 2 Bonus Issue Ratio of NSE listed companies during 2014-2018

\begin{tabular}{|l|c|c|c|c|c|c|c|}
\hline Bonus Issue Ratio & $\mathbf{2 0 1 8}$ & $\mathbf{2 0 1 7}$ & $\mathbf{2 0 1 6}$ & $\mathbf{2 0 1 5}$ & $\mathbf{2 0 1 4}$ & Total & Ratio (\%) \\
\hline One for One & 10 & 10 & 10 & 15 & 6 & 51 & 61.00 \\
\hline One for Two & 5 & 4 & 3 & 2 & - & 14 & 16.87 \\
\hline One for Three & 1 & 1 & - & - & - & 2 & 2.40 \\
\hline One for Ten & 2 & 4 & - & - & - & 6 & 7.23 \\
\hline Two for One & 1 & 2 & 1 & 1 & - & 5 & 6.02 \\
\hline One for Four & - & 1 & - & - & - & 1 & 1.20 \\
\hline Two for Five & - & - & 2 & - & - & 2 & 2.41 \\
\hline Three for One & - & - & 1 & - & - & 1 & 1.20 \\
\hline One for One thousand & - & - & - & - & 1 & 1 & 1.20 \\
\hline
\end{tabular}

Source: Authors own calculations.

Out of the following events, those related to banking and finance industries are included in the sample. A total of five finance companies and three banking companies announced bonus issue, whereas City Union Bank announced bonus issue in two consecutive years, in 2017 and 2018.

\section{FINDINGS AND INTERPRETATIONS}

Table 4.1 describes the descriptive statistics mainly mean, standard deviation, maximum and minimum of ARs of sample stocks undertaken for the study. Mean is one of the measure of central tendency and is defined as a single value which is considered as the most typical or representative value for a given set of data. Minimum and maximum shows the minimum and maximum AR value of a sample stock. Variance tells the extent to which observations vary from some average value. 
An Empirical Analysis of Stock Price Behaviour around Bonus Issue Announcement in India

Table 3 Basic Statistics Results

\begin{tabular}{|c|l|c|c|c|c|}
\hline Sr. No. & \multicolumn{1}{|c|}{ Companies } & Minimum & Maximum & Mean & $\begin{array}{c}\text { Standard } \\
\text { Deviation }\end{array}$ \\
\hline 1 & ICICI Bank & -0.0150 & 0.0055 & -0.0006 & 0.0041 \\
\hline 2 & Bajaj Finance & -0.0103 & 0.0087 & -0.0005 & 0.0039 \\
\hline 3 & DHFL & -0.0062 & 0.0047 & -0.0014 & 0.0030 \\
\hline 4 & City Union Bank - 2018 & -0.0122 & 0.0046 & 0.0003 & 0.0035 \\
\hline 5 & City Union Bank - 2017 & 1.9164 & 1.9299 & 1.9221 & 0.0039 \\
\hline 6 & Karur Vysya Bank & -0.0085 & 0.0068 & -0.0010 & 0.0032 \\
\hline 7 & Power Finance Corp. & -0.0085 & 0.0045 & -0.0025 & 0.0042 \\
\hline 8 & Kotak Mahindra Bank & 1.2157 & 1.2321 & 1.2241 & 0.0033 \\
\hline 9 & Muthoot Finance & -0.00611 & 0.0069 & -0.0005 & 0.0036 \\
\hline
\end{tabular}

\subsection{Average Abnormal Return of Select Stocks}

The present study tests the semi strong form of Indian Capital Market with special reference to bonus issue announcements of 9 sample companies. The AAR value of selected stocks, their sign and t-statistics and their significance at $5 \%$ level over the event window.

Table 4 Impact of bonus issue announcement on return of selected stocks:

\begin{tabular}{|l|c|c|c|c|c|}
\hline \multicolumn{1}{|c|}{ Banks } & AARs over the & Signs & t-value & p-value & Significant at 5\% \\
\hline ICICI Bank & $-0.0006 \%$ & - & -0.712 & 0.485 & Not Significant \\
\hline Bajaj Finance & $-0.0004 \%$ & - & -0.584 & 0.566 & Not Significant \\
\hline DHFL & $-0.0013 \%$ & - & -2.119 & 0.047 & Significant \\
\hline City Union Bank - 2018 & $0.0003 \%$ & + & 0.409 & 0.687 & Not Significant \\
\hline City Union Bank - 2017 & $1.9220 \%$ & + & 2275.831 & 0.000 & Significant \\
\hline Karur Vysya Bank & $-0.0010 \%$ & - & -1.470 & 0.157 & Not Significant \\
\hline Power Fin. Corp. & $-0.0024 \%$ & - & -2.722 & 0.013 & Significant \\
\hline Kotak Mahindra Bank & $1.2240 \%$ & + & 1690.714 & 0.000 & Significant \\
\hline Muthoot Finance & $-0.0004 \%$ & - & -0.628 & 0.537 & Not Significant \\
\hline
\end{tabular}

*Significant at $5 \%$ level of significance.

The above table shows that out of 9 banking and finance companies, 6 stocks have negative AARs and 3 have positive AARs. The AARs value ranges from lowest -0.0024 of Power Finance Corporation to highest value 1.9220 of City Union Bank-2017. Among all sample companies, only four sample stocks' ARR (Dewan Housing Finance Corporation, City Union Bank-2017, Power Finance Corporation, and Kotak Mahindra Bank) are found significant, that means shareholders of these companies have earned abnormal returns during event window and other five stocks' AARs are found to be insignificant. Hence, it evidences semi-strong form of Indian stock market at primary level in case of banking and finance companies. Out of the four significant results, two have positive abnormal returns and two have negative abnormal return. DHFL and Power Finance Corporation have negative abnormal return, which is significant. City Union Bank-2017 and Kotak Mahindra Bank have positive abnormal returns, which are significant.

In case of DHFL, City Union Bank-2017, Power Finance Corporation and Kotak Mahindra Bank, we accept the null hypothesis that there is significant impact of bonus issue on the stock price during 2014-2018. Moreover, in case of ICICI Bank, City Union Bank-2018, Karur Vysya Bank and Muthoot Finance we reject the null hypothesis and say that there is no significant impact of bonus issue on stock prices. 


\subsection{Average Abnormal Return and Cumulative Average Abnormal Return of stocks}

Share price reaction of 9 companies during the event window of 21 days $\left(t_{-10}\right.$ to $t_{+10}$ including event day) is assessed by calculating the average abnormal return and to know the persistence of effect of information on price, the cumulative average abnormal returns are calculated. To know their statistical significance, $t$ - test is applied and the results are shown in below table.

Table 5 AARs and CAARs of sample stocks during event window:

\begin{tabular}{|c|c|c|c|c|c|c|c|}
\hline & \multirow{2}{*}{ AAR } & \multirow{2}{*}{ t-value } & \multirow{2}{*}{ Df } & \multirow{2}{*}{ p-value } & \multirow{2}{*}{ CAAR } & \multicolumn{2}{|c|}{ 95\% Confidence interval } \\
\cline { 6 - 8 } & & & & & & Lower & Upper \\
\hline 10 & 0.348 & 1.463 & 8 & 0.182 & 0.348 & -.201018 & .898724 \\
\hline 9 & 0.348 & 1.461 & 8 & 0.182 & 0.697 & -.201621 & .898670 \\
\hline 8 & 0.348 & 1.465 & 8 & 0.181 & 1.046 & -.200428 & .898136 \\
\hline 7 & 0.349 & 1.469 & 8 & 0.180 & 1.396 & -.199295 & .899061 \\
\hline 6 & 0.348 & 1.461 & 8 & 0.182 & 1.744 & -.201434 & .897552 \\
\hline 5 & 0.350 & 1.471 & 8 & 0.179 & 2.094 & -.198967 & .900366 \\
\hline 4 & 0.349 & 1.463 & 8 & 0.182 & 2.444 & -.201356 & .899718 \\
\hline 3 & 0.349 & 1.462 & 8 & 0.182 & 2.792 & -.201320 & .898553 \\
\hline 2 & 0.348 & 1.463 & 8 & 0.182 & 3.140 & -.200840 & .897292 \\
\hline 1 & 0.348 & 1.462 & 8 & 0.182 & 3.489 & -.201051 & .898228 \\
\hline 0 & 0.348 & 1.456 & 8 & 0.183 & 3.837 & -.203089 & .899088 \\
\hline-1 & 0.346 & 1.447 & 8 & 0.186 & 4.184 & -.205454 & .898202 \\
\hline-2 & 0.348 & 1.465 & 8 & 0.181 & 4.532 & -.200069 & .897177 \\
\hline-3 & 0.349 & 1.466 & 8 & 0.181 & 4.881 & -.200169 & .898348 \\
\hline-4 & 0.349 & 1.461 & 8 & 0.182 & 5.230 & -.201762 & .899485 \\
\hline-5 & 0.348 & 1.460 & 8 & 0.182 & 5.578 & -.201425 & .897213 \\
\hline-6 & 0.350 & 1.464 & 8 & 0.181 & 5.928 & -.201419 & .902002 \\
\hline-7 & 0.350 & 1.467 & 8 & 0.181 & 6.279 & -.200492 & .901773 \\
\hline-8 & 0.349 & 1.465 & 8 & 0.181 & 6.628 & -.200799 & .900016 \\
\hline-9 & 0.348 & 1.457 & 8 & 0.183 & 6.976 & -.202881 & .899169 \\
\hline-10 & 0.349 & 1.465 & 8 & 0.181 & 7.326 & -.200767 & .900152 \\
\hline
\end{tabular}

*Significant at $5 \%$ level of significance.

Source: Compiled from NSE Ltd.

Table 5 shows that the result obtained by computing the ARRs and CAARs for the 9 companies bonus issue announcements for 21 days in the event window and respective t-value and p-value. ARRs and CAARs with their respective values along with their significance at 5\% level are analyzed. The event day generated a positive AAR of 0.348 which was significant at $5 \%$ level.

During the pre-announcement period of the event window, there was equality in the ARRs. It was positive for all days. In this period, the ARRs ranged from lowest value of $0.346 \%$ to the highest value of $0.350 \%$ from $5^{\text {th }}$ day to $7^{\text {th }}$ day. The AARs pre and post the announcement are approximately same, so we can say that there is no significant impact of bonus issue on the stock prices in the event window.

During the event window period, the ARRs of every day were not significant because the p-value is greater than 0.05 , which shows that we accept the null hypothesis and say that there is no significant impact of bonus issue announcement on the stock prices from $t-10$ to $t+10$. There is no significant abnormal return on any day from pre-announcement to post- 
announcement. In the event days, we accept the null hypothesis and reject the alternate hypothesis.

Table 5 also shows the analysis of CAARs of bonus issue announcements. An analysis of CAARs during the pre-announcement period shows that CAARs for all days were positive. On every day it is found that p-value is higher than 0.05 , which shows that null hypothesis is true and there is no impact of bonus issue announcement on the stock prices. On the announcement date the value of CAAR is 3.837 which is found statistically not significant. This signifies that investors have not earned abnormal returns during event window period.

\section{CONCLUSION}

The present study attempts to examine the efficiency of Indian stock market in relation to the impact of bonus issue announcement. In order to attain the objectives of the study, hypotheses are made such as $\mathrm{H}_{0}$ : There is no significant impact of bonus issue announcement on the stock prices, $\mathrm{H}_{1}$ : There is significant impact of bonus issue announcement on the stock prices. A 21 days event window has been employed in order to analyze the abnormal returns, window starts on the $10^{\text {th }}$ day prior to the event day and ends on the $10^{\text {th }}$ day after the event day and a period of 120 days as estimation window, begins from day -140 and ends on day -11 and is taken in order to compute parameters $(\alpha$ and $\beta$ ) for market model. Market model is employed for computation of expected return i.e. $\mathrm{E}(\mathrm{R})=\alpha+\beta^{*} \mathrm{Rm}$.

The analysis based on AARs of individual sample companies during the event window reveals that out of 9 sample companies, 3 stocks have provided positive abnormal returns and remaining 6 have negative AARs. Among all sample companies, only 4 sample stocks' AARs found significant, i.e. shareholders of these companies might have earned abnormal returns during event window and other 5 stocks' AAR are found insignificant. On this basis it can be said that Indian stock market is semi strong efficient at primary level in case of banking and finance companies.

The analysis based on AARs \& CAARs reveals that during the event window of 21 days, not a single day shows significant abnormal return. Pre-announcement period as well as postannouncement shows positive AAR and p-values more than 0.05 , which denotes that during the event window period there is no abnormal returns. From these results we can conclude that there is no insider information leaked during the event window in case of banking and finance companies.

\section{SCOPE FOR FURTHER RESEARCH}

In Indian context, there are few attempts taken to study bonus issue announcement and its impact on stock prices. This can be furthered by taking the following aspects relating to corporate announcements and other publicly available information.

- Different sector-wise analysis of stocks

- Other corporate announcements like stock split, cash dividend, right issue, earnings, merger \& acquisitions, stock repurchase etc.

- On the basis of number of variables studied, more variables can also be considered like economic, political variables and trading frequencies etc.

- A further research can be done in this regard in order to find out the reasons and the factors behind this. 


\section{REFERENCES}

[1] Ahsan, M., Chowdhury, R., Sarkar, A. H, An Empirical Study on Market Reaction around the Bonus Issues Announcements in Bangladesh. International Journal of Economics and Finance, 6(1), 2014, pp 82-98.

[2] Ayodele, A., \& Maxwell, O. O, Test of the Semi-Strong Efficiency Theory in the Nigerian Stock Market: An Empirical Analysis. Journal of Finance and Accounting, 5(4), 2017, pp 139-146.

[3] Below, S. D. \& Johnson, K. H, An Analysis of Shareholder Reaction to Dividend Announcements in Bull and Bear Markets. Journal of Finance \& Strategic Decisions, 9(3), 1996, pp 15-26.

[4] Chai, M. L., \& Tung, S, The effect of earnings-announcement timing on earnings Management. Journal of Business Finance \& Accounting, 29(9), 2002, pp 1337-1354.

[5] Dhar, S., \& Chhaochharia, S, Market Reaction around the Stock Splits and Bonus Issues: Some Indian Evidence. Retrived from: Https://Ssrn.Com/Abstract=1087200, 2008

[6] Dhatt, M. S., Kim, Y. H., \& Mukherji, S, The role of stock dividends in Korea. Global Finance Journal, 8(2), 1997, pp 295-308.

[7] Gachuhi, P. M., \& Iraya, C, Effect of Bonus issue on Stock Prices of Companies Quoted at the Nairobi Securities Exchange. International Journal of Finance, 2(1), 2017, pp 1-16.

[8] Grinblatt, M., Masulis, R., \& Titman, S, The Valuation Effects of Stock Splits and Stock Dividends. Journal of Financial Economics, 13(4), 1984, pp 461-490.

[9] Gupta, V, Announcement Effects of Bonus Issues on Equity Prices: The Indian Experience. Indian Journal of Finance and Research, 13(1\&2), 2003

[10] Hua, L. \& Ramesh, S, A Study on Stock Split Announcements and its impact on Stock Prices in Colombo Stock Exchange (CSE) of Sri Lanka. Global Journal of Management and Business Research Finance, 13(6), 2013, pp 24-34.

[11] Kumar, S., \& Halageri, S, Testing the Semi Strong Form Efficiency of Indian Stock Market with respect to information content of Bonus Announcement. International Journal of Exclusive Management Research, 1(3), 2011, pp 250-280.

[12] Laidroo, L, Public announcement induced market reactions on Baltic stock exchanges. Baltic Journal of Management, 3(2), 2008, pp 174-192.

[13] Lijleblom, E, The informational impact of announcements of stock dividends and stock splits. Journal of Business Finance and Accounting, 16(5), 1989, pp 681-698.

[14] Malhotra, M., Thenmozhi, M., \& Kumar, A. G, Stock Market Reaction and Liquidity Changes around Bonus Issue Announcement: Evidence From India. In $10^{\text {th }}$ Capital Markets Conference, Indian Institute of Capital Markets, 2007

[15] McNichols, M., \& Dravid, J, Stock Dividends, Stock Splits and Signalling. Journal of Finance, 50(1), 1990, pp 1-10.

[16] Mishra, A. K, An Empirical Analysis of Market Reaction Around Bonus Issue in India. ICFAI Journal of Applied Finance, 11(7), 2005, pp 21-39.

[17] Patell, J. M., \& Wolfson, M. A, The intraday speed of adjustment of stock prices to earnings and dividend announcements. Journal of Financial Economics, 13(2), 1984, pp 223- 252.

[18] Purohit, H., Satija, V. D., Chhatwal, H. S, Market Reaction around the buyback announcements in India: An empirical analysis of Market Efficiency. Journal of Management, Computer Science \& Journalism, 7(1), 2012, pp 7-14 
An Empirical Analysis of Stock Price Behaviour around Bonus Issue Announcement in India

[19] Raja, M. \& Sudhahar, J. C, An empirical test on Indian Stock Market efficiency in respect of Bonus Announcement. Asia Pacific Journal of Finacnce and Banking Research, 4(4), 2010, pp 1-14.

[20] Ramachandran, R, A Study on Semi Strong Efficiency of Indian Stock Market. Indian Journal of Scientific and Research Publications, 3(9), 2013, pp 1-3.

[21] Rane, A. \& Guntur, A. R, Dividend Announcement and Market Efficiency - An Empirical Study on Service Sector Companies listed in BSE. Journal of Management, 10, 2017

[22] Rao, S. N., \& Lukose, P. J. J, Does bonus issues signal superior performance? A study of the BSE Listed Firms. Decision, 32(1), 2005, pp 39-64

[23] Ray, K. K, Market Reaction to Bonus issues and Stock Splits in India: An Empirical Study. The IUP Journal of Applied Finance, 17(1), 2011, pp 54-69.

[24] Salamudin, N., Ariff, M., \& Nassir, A. M. (1999). Economic influence on rights issue announcement behaviour in Malaysia. Pacific-Basin Finance Journal, 7, 1999, pp 405427.

[25] Sriram, M., \& Senthil, M, Effect of stock splits on price, returns and volume of trade evidence from India. Journal for Managerial Finance and Research, 1(2), 2009, pp 363373. 